\title{
Kajian parameter gender dalam substansi peraturan perundang- undangan di Indonesia
}

\author{
Kadek Wiwik Indrayanti.
}

Kadek Wiwik Indrayanti; Fakultas Hukum Universitas Merdeka Malang; Jl. Terusan Raya Dieng Nomor 62-64; Malang; 65146; Jawa Timur; Indonesia.

\begin{tabular}{l}
\hline A R T I C L E I N F O \\
\hline Article history: \\
Received 2021-04-26 \\
Received in revised form \\
2021-07-07 \\
Accepted 2021-08-01 \\
\hline
\end{tabular}

Kata kunci:

Keseteraan Gender; Parameter Gender; Diskriminasi; Keadilan.

\section{Keywords: \\ Gender equality; Gender \\ parameters; Discrimination; Justice.}

DOI: $h$ ttps://doi.org/10.26905/

idjch.v12i2.6223.

\section{How to cite item:}

Indrayanti, KW (2021). Kajian parameter gender dalam substansi peraturan perundangundangan di Indonesia. Jurnal Cakrawala Hukum, 12(2), 295-204 doi:10.26905/idjch.v12i2.6223.
Corresponding Author:

* Kadek Wiwik Indrayanti.

E-mail address: kadek.indrayanti@unmer.ac.id.

\section{Abstrak}

Artikel ini mengkaji tujuan, prinsip, dan pengintegrasian indikator kesetaraan gender dalam penyusunan undang - undang. Metode yang digunakan adalah penelitian hukum normatif karena mengkaji beberapa substansi undang undang yang bias gender. Hasilnya menunjukkan bahwa peran pemerintah dalam mewujudkan kesetaraan gender di Indonesia dewasa ini sudah dilakukan melalui peraturan perundang-undangan, kebijakan-kebijakan dan program-program namun masih harus diperjuangkan karena realitasnya masih ada kesenjangan antara kedua jenis kelamin, yang berdampak terjadi diskriminasi gender. Beberap Undang Undang yang subsatnsinya menunjukkna diskriminsi terhadap peremuan seperti Undang Undang Perkawinan. Oleh karena itu maka konsep kesetaraan gender sudah seyogyannya dipahami sebagai sebuah "Tujuan", agar kedua jenis kelamin sebagai warga negara dapat memperoleh hak haknya. Ada tiga prinsip yang harus mendapatkan perhatian yaitu kesetaraan mendasar, non diskriminasi dan kewajiban Negara yang menjadi pintu pembuka untuk memperbaiki kondisi ketidak setaraan gender dimasyarakat. Kedua prinsip itu seyogyanya diakomodasi kedalam peraturan perundangan undangan. Selanjutnya 4 indikator gender yaitu akses, partisipasi, kontrol dan kesempatan seyogyanya dimasukkan secara terintegrasi mulai pembuatan suatu produk hukum, kemudian dijabarkan kedalam kebijakan dan program.

\section{Abstract}

This article examines the objectives, principles, and integration of gender equality indicators in the formulation of laws. The method used is normative legal research because it examines some of the substance of laws that are gender biased. The results show that the role of the government in realizing gender equality in Indonesia today has been carried out through laws and regulations, policies and programs but still has to be fought for because in reality there is still a gap between the two sexes, which 


\section{Jurnal Cakrawala Hukum, Volume 12 No. 2 Agustus 2021}

ISSN PRINT 2356-4962 ISSN ONLINE 2598-6538

has an impact on gender discrimination. There are several laws whose substance shows discrimination against women, such as the Marriage Law. Therefore, the concept of gender equality should be understood as a "goal", so that both sexes as citizens can obtain their rights. There are three principles that must receive attention, namely basic equality, non-discrimination and the obligation of the State which is the opening door to improve conditions of gender inequality in society. These two principles should be accommodated in the legislation. Furthermore, the 4 gender indicators namely access, participation, control and opportunity should be integrated in an integrated manner starting from the manufacture of a legal product, then translated into policies and programs.

\section{Pendahuluan}

Kesetaraan gender merupakan konsep kesamaan hak dimana laki laki dan perempuan memiliki akses, kesempatan, partisipasi dan kontrol secara setara sehingga dapat memberikan kontribusi didalam pembangunan disegala aspek kehidupan (UNICEF, 2017: hal 11). Sehingga berbicara tentang kesetaraan gender bertujuan untuk mencapai keadilan gender. Keadilan gender akan terwujud jika perlakuan diskriminiasi tidak dirasakan oleh kedua jenis kelamin (https:/ / idtesis.com/kesetaraan-gender-2).

Kondisi kesetaraan gender di Indonesia dewasa ini sudah dilakukan oleh pemerintah baik melalui peraturan perundang-undangan, kebijakankebijakan dan program-program namun masih harus diperjuangkan karena realitasnya masih ada kesenjangan antara kedua jenis kelamin, yang berdampak terjadi diskriminasi gender. Kesenjangan itu terjadi tidak hanya dikalangan masyarakat tetapi dilingkungan instansi pemerintah. Pemerintah seyogyanya dicarikan pemecahannya dengan menggunakan pendekatan secara holistik.

Seperti kajian yang dilakukan di berbagai instansi dilingkungan dinas pemerintah didaerah masih menunjukkan bahwa pengaruh perempuan dalam pengambilan keputusan masih rendah baik di ranah komunitas maupun di rumah tangga (Dewi dan Kadek, 2019). Senada dengan temuan
S. Akter et al. www.elsevier.com/locate/foodpol). Hal Ini menunjukkan bahwa pengarustamaan gender dilingkungan dinas-dinas dan institusi lainnya belum maksimal karena pemahaman tentang konsep konsep gender seperti gender budgeting dan gender focal poit belum dimiliki. Sementara sistem kekerabatan patrilinial yang masih kental dianut masyarakat seperti di Sumba, Bali, Flores dll. Dapat dilhat dari posisi sebagai kepala dinas diduduki oleh laki laki. Beberapa kendala yang dihadapi oleh dinas-dinas dalam melaksanakan programprogram gender mainstreaming disebabkan minimnya anggaran, sumber daya manusia, tradisi dan technologi. Komitmen untuk memperbaiki kesenjangan ini hendaknya dimulai dari jajaran pimpinan melalui pengembangan secara praktik dan program - pragram training yang ditujukan pada instistusi dan stake holder lainnya (Dewi dan Kadek 2020). Senada dengan kajian yang dilakukan di negara Afrika (https://www.un.org/en/africa/ osaa/pdf/au/gender policy_2009.p.).

Sementara itu peran negara mulai dari level kementerian sampai jajaran di bawahnya telah mengeluarkan Inpres No 9 Tahun 2000 tentang Pengarusutamaan Gender (PUG) telah diimplementasikan. Namun hasilnya masih harus dilakukan evaluasi dan monitoring. Untuk mempercepat kondisi pengarus utamaan gender dimasyarakat dan di institusi, maka salah satunya adalah mengkaji dan menganalisis apakah indikator 


\section{Kajian parameter gender dalam substansi peraturan perundang-undangan di Indonesia}

Kadek Wiwik Indrayanti

kesetaraan gender sudah dimasukkan didalam substansi peraturan perundangan. Untuk itu, kajian terkait kendala-kendala gender mainstreaming perlu dilakukan sehingga dapat diidentifikasi dan dicarikan jalan keluarnya. Beberapa kendala yang ada disebabkan adanya pemikiran dikalangan banyak kalangan ketika mendengar kata gender sudah dianggap sebagai pendobrak. Belum lagi hambatan disebabkan oleh sistem masyarakat patrilineal dengan sistem hukum adatnya yang memberikan ruang lebih kepada kaum laki laki. Sehingga berdampak dilevel instistusi dan pada pembuatan suatu produk hukum yang bias gender.

Kebijakan-kebijakan gender mainstreaming didalam peraturan perundang undangan seyogyanya memberikan perlindungan kepada hak-hak warga negara. Ketika awalnya perlindungan hak asasi tidak difokuskan untuk perlindungan terhadap hak hak perempuan, sementara hukum internasional mewajibkan hak asasi penting sebagai dasar atau landasan gender mainstreaming. Perkembangan menunjukkan bahwa hak hak perempuan merupakan hak asasi manusia.

Dengan dimasukkannya Parameter Kesetaraan Gender kedalam hukum positif diharapkan terwujudnya keadilan gender sehingga berkurangnya ketimpangan diantara kedua jenis kelamin. Untuk itu perlu dilakukan suatu kajian dan revisi terhadap substansi hukum positif termasuk teknis kebijakan operasional yang sensitif dan responsif gender

Sebenarnya dari aspek pembuatan kebijakan telah dilakukan oleh pemerintah Indonesia dengan merujuk pada beberapa konvensi internasional seperti Konferensi Hak Asasi Manusia di Wina (1993) mengupayakan keterlibatan kaum wanita disegala aspek kehidupan; menurukan tindak kekerasan berdasarkan jenis kelamin. Kemudian Konferensi Wanita Sedunia di Beijing 1995 rekomendasinya mewajibkan negara dunia untuk mengimplementasi "gender mainstreaming. Konferensi ICPD di Kairo (International Conference on
Population Development) juga menyatakan bahwa pemberdayaan perempuan (women's empowerment) dipandang sebagai alat untuk pengembangan dan stabilitas kependudukan. Selanjutnya The Convention for the Elimination of All Discrimination Against Women (CEDAW) pada artikel 14 (2) menyerukan untuk mengurangi diskriminasi perempuan di pedesaan termasuk hak untuk menikmati kondisi hidup yang cukup khususnya di bidang perumahan, sanitasi, listrik dan penyediaan air. Di Indonesia perjanjian internasioan tersebut dijadikan dasar melalui Inpres No. 9 Tahun 2000 tentang Pengarusutamaan Gender dalam Pembangunan Nasional, yang mengintruksikan agar mengimplementasikan pengarusutamaan gender (PUG) mulai dari jajaran Kementerian sampai Walikota sesuai dengan peran masing masing mulai dari proses perencanaan, penyusunan, pelaksanaan, pemantauan dan evaluasi terhadap kebijakan dan program pembangunan nasional yang berperspektif gender. Selanjutnya Surat Keputusan Menteri Negara Pemberdayaan Perempuan Nomor 23/SK/MENEG.PP/VI/ 2001 tentang Pedoman Penetapan Stándar Pelayanan Minimal (SPM) Pemberdayaan Perempuan di Provinsi, Kabupaten/Kota sebagai Daerah Otonom. Kemudian Keputusan Presiden RI Nomor 88 Tahun 2002 tentang Rencana Aksi Nasional (RAN) Penghapusan Perdagangan (trafficking) Perempuan dan Anak. Keputusan Menteri Dalam Negeri (Kepmendagri) Nomor 132 Tahun 2003 tentang Pedoman Umum Pelaksanaan PUG dalam Pembangunan di Daerah yang menginstruksikan setiap institusi pemerintah melaksanakan PUG. Inilah bukti bahwa pemerintah telah berkomitmen untuk menerapkan kesetaraan gender sebagai sebuah "Tujuan" yang diatur didalam Perpres SDGs Nomor 59 Tahun 2017 tentang Pelaksanaan Pencapaian Tujuan Pembangunan Berkelanjutan. Adapun TUJUAN ke 5 adalah mencapai kesetaraan gender dan memberdayakan perempuan. (Pembangunan Manusia Indonesia berbasis gender, 2019) 
Seperti contoh yang dapat dikaji kebijakan di lingkungan Peradilan telah melaksanakan gender mainstreaming dengan dikeluarkannya Peraturan Mahkamah Agung No. 3 Tahun 2017 tentang Pedoman Mengadili Perkara Perempuan Berhadapan dengan Hukum pada tanggal 11 Juli 2017. Diwajibkan untuk para Hakim dalam persidangan ketika berkomunikasi memperhatikan keadilan gender dan memiliki pemahaman tentang persamaan baik yang tertuang dalam hukum positif, hukum adat secara non diskriminasi. Perma Nomor 3 Tahun 2017 dikeluarkan karena perilaku hakim dalam menangani kasus pemerkosaan menyudutkan korban anatra lain mengajukan pertanyan vulgar dalam proses pemeriksaan korban, sikap hakim yang menertawakan korban dan mengatakan, kalau korban juga sangat menikmati hubungan tersebut. Sehingga korban menjadi tertekan, menangis dan merasa disudutkan $(\mathrm{LBH}$ APIK dalam http:/ / mappifhui.org/wp-content/ uploads/2018/01/Pedoman-Mengadili-PerkaraPerempuan-Berhadapan-dangan-Hukum-MaPPIFHUI-2018.pdf ).

Selanjutnya ketidak adilan gender masih dirasakan khususnya oleh perempuan dengan mengidentifikasi peraturan perundang undangan masih terdapat yang bias gender sehinga belum mencerminkan keadilan. Ada 7 undang -undang yang yang perlu direvisi karena kandungannya bias gender antara lain Undang Undang Perkawinan (https:/ / nasional.kompas.com/read/2016/ 03/06/17335421/Diskriminasi.Gender.Tujuh. UU.Terkait.Perempuan). Didalam UndangUndang Republik Indonesia Nomor 16 Tahun 2019 tentang Perubahan Atas Undang-Undang Nomor 1 Tahun 1974 tentang Perkawinan, masih menyisakan problem bagi kaum perempuan dan anak terkait kedudukan kedudukan perempuan, poligami, nikah siri, kawin kontrak perkawinan dibawah umur belum sepenuhnya mengandung unsur kesetaraan gender.
Kajian terhadap materi Undang-Undang Republik Indonesia Nomor 16 Tahun 2019 tentang Perubahan Atas Undang-Undang Nomor 1 Tahun 1974 tentang Perkawinan. Ada beberapa yang diskriminasi dan bias gender. Salah satu fenomena yang dilakukan oleh masyarakat Muslim yaitu melakukan nikah siri. Nikah siri adalah pernikahan yang dilakukan oleh seseorang, memenuhi rukun dan syarat nikah namun tidak didaftarkan di Kantor Urusan Agama (KUA). Kasus nikah siri dan pernikahan di bawah umur ini bukan hal baru. Dalam sensus yang dilakukan oleh lembaga swadaya masyarakat (LSM) Pemberdayaan perempuan Kepala Keluarga (Pekka), sebanyak 25 persen masyarakat di Indonesia melakukan kawin siri dan nikah secara adat pada tahun 2012. Artinya pernikahan ini tidak tercatat di negara (https://www. merdeka.com/ peristiwa/25-persen-masyarakatindonesia-melakukan-nikah-siri.html). Didalam ketentuan agama Islam Nikah Siri memang dibolehkan dalam arti sah dimata agama Islam, namun tidak mendapat pengakuan dari negara. Artinya status hukum tidak dimiliki oleh anak yang dilahirkan dan istri. Untuk memperoleh akta perkawianan maka diwajibkan untuk mencatatkan perkawinannya. Adanya akte perkawinan merupakan bukti telah terjadinya suatu perkawinan, bukan menentukan keabsahan suatu perkawinan. Dalam Nikah Siri tidak dicatatkan akibat hukumnya adalah anak akan dinggap sebagai anak luar kawin yang hanya memiliki hubungan keperdataan dengan ibu dan keluarga ibunya. Selama Januari September 2020, jumlah pernikahan anak di Jatim sebanyak 197.068 kasus. Dari jumlah tersebut, kasus terbanyak terjadi di Jember dengan jumlah 13.269 kasus. Disusul Kabupaten Malang sebanyak 12.894 kasus. Surabaya 11.112 kasus (https:// daerah. sindonews.com/read/297502/704/januariseptember-2020).

Kemudian didalam Undang Undang Nomor 20 tahun 2020 tentang Cipta Kerja banyak sekali 


\section{Kajian parameter gender dalam substansi peraturan perundang-undangan di Indonesia}

Kadek Wiwik Indrayanti

hak dan perlindungan perempuan yang diabaikan. Substansi Undang-Undang Cipta Kerja menunjukkan tidak memberikan perlindungan terhadap hak cuti haid dimana disebutkan bahwa perusahaan tidak ada kewajiban untuk membayar upah atas cuti tersebut. Disamping itu mayoritas pekerja perempuan pada padat karya terjadi penurunan standar upah yang berdampak pada pendapatan yang akhirnya menurunkan pada upaya pemenuhan hidup yang layak bagi dirinya, Disamping itu dalam kontrak kerja mengakibatkan kelemahan pada posisi buruh perempuan (https://wolipop. detik.com/worklife/d-4866087/2-aturan-omnibuslaw-yang-merugikan-pekerja-wanita-kamu-wajibtahu).

Atas dasar itulah maka paper ini bertujuan untuk mengidentifikasi dan menganalis tujuan, prinsip, dan pengintegrasian indikator kesetaraan gender dalam penyusunan undang - undang. Disamping itu paper ini mengkaji konsep konsep gender yang dijadikan dasar untuk memastikan dimasukkan kedalam peraturan perundang undangan.

\section{Metode}

Kajian ini merupakan penelitian normatif karena mengkaji peraturan perundangan undangan, yang memasukkan indikator gender kedalamnya, prinsip dan kebijakan-kebijakan pengarusutamaan gender. Analisis yang digunakan adalah analisis gender yaitu dengan mengamati dan menganalisa apakah akses, kesempatan, kontrol dan partisipasi antara kedua jenis kelamin sudah dimasukkan kedalam substansi peraturan perundangan. Teori yang juga dipakai untk mendukung adalah teori perlindungan hukum dan prinsip kesetaraan yang merupakan bagian dari hak asasi.

\section{Pembahasan}

Kondisi kesetaraan gender di Indonesia yang diharapkan dapat dirasakan oleh masyarakat khusuanya kaum perempuan tidak bisa lepas dengan aspek pembangunan manusia Indonesia secara umum. Untuk itu maka konsep kesetaraan gender sudah seyogyannya dipahami sebagai sebuah "Tujuan", yang merupakan suatu tujuan untuk memperoleh hak haknya bagi kedua jenis kelamin sebagai warga negara. Sehingga memiiliki kapasitas menjalankan perannya dan berpartisipasi sehingga hasil pembanguna dapat dirasakan tanpa diskriminasi. Untuk itu pemerintah melalui Perpres SDGs Nomor 59 Tahun 2017 tentang Pelaksanaan Pencapaian Tujuan Pembangunan Berkelanjutan. Dimana tujuan ke-5 adalah untuk mencapai kesetaraan gender dan pemberdayaan perempuan. Salah satunya untuk mengurangi perilaku diskriminatif terhadap kaum perempuan dimanapun. Adapun indikatornya adalah jumlah peraturan dan kebijakan yang responsive gender yang mendukung pemberdayaan perempuan. Kemudian melakukan perubahan seperti memberikan akses dibidang ekonomi, kontrol atas tanah dan bentuk kepemilikan dan warisan sesuai dengan hukum nasional.

Dalam rangka memperjuangkan kesetaaraan gender di dunia maka ada tiga prinsip yang merupakan dasar bagi CEDAW yang harus mendapatkan perhatian yaitu Kesetaraan Mendasar, Non Diskriminasi dan kewajiban Negara yang menjadi pintu pembuka untuk memperbaiki kondisi ketidak setaraan gender dimasyarakat. (ttps://www.kemenpppa.go.id/lib/uploads/list/ c3196-parameter-kesetaraan-gender-dalampembentukan-peraturan-perundang-undangan. pdf:26).

Prinsip itu seyogyanya diakomodasi kedalam peraturan perundangan undangan meng- 
ingat kondisi masyarakat yang majemuk (plural) dengan system masyarakat hukum adat dengan sistem partilinial yang masih sangat kental merupakan salah satu terjadinya ketidak adilan gender. Akibatnya ketertinggalan pengalaman kaum perempuan baik diranah publik dan privat. Dengan menggunakan pedekatan kesetaraan bertujuan untuk menghilangkan ketidak samaan, marginalisasi yang dialami oleh kelompok masyarakat baik secara individu atau secara kelembagaan. Dengan memasukkan kesetaraan secara subtansi kedalam hukum positif yang diikuti kedalam kebijakan dibawahnya serta program program di berbagai institusi pemerintah, sehingga harapan yang teruang didalam CEDAW dapat diwujudkan.

Kemudian prinsip Non Diskriminasi seharusnya mengacu pada asas yang diatur didalam Undang Undang Dasar Negara Republik Indonesia Tahun 1945 dan seyogyanya sudah selaras dengan ketentuan Pasal 1 CEDAW dan dapat dijadikan alat untuk mengakaji dan menganalisis substansi peraturan perundangan undangan. Kemudian dilakukan analisa dengan mengidentifikasi perbedaan antara kebutuhan kedua jenis kelamin apakah disebabkan karena tradisi dan norma. Selanjutnya prinsip yang ketiga adalah kewajiban Negara yakni peran pemerintah didalam menciptakan kondisi kesetaran dan non diskriminasi melalui peraturan dan juga mewujudkan secara de facto. Untuk mewujudkan kesetaraan gender di berbagai aspek kehidupan masyarakat maka maka ketentuan didalam peraturan nasional dengan merujuk pada konferensi internasional yang mewajibkan Negara untuk meratifikasi dan memasukkan kedalam hukum positifnya guna mengurangi diskriminasi diantara kedua jenis kelamin. Ada tiga tahapan yang seyogyannya dilakukan oleh Negara yakni meratifikasi konvensi internasional terkait, kemudian memasukkannya kedalam hukum positif agar masyarakat dapat memiliki hak haknya. Yang terakhir, agar masyarakat dapat merasakan haknya haknya meru- pakan hal yang harus dilakukan negara untuk memastikan apakah masyarakat sudah merasakannya? Untuk mewujudkan itu memang tugas pemerintah denggan support baik dari masyarakat maupun lembaga lembaga pendonor (nasional dan internasional). Jika negara meratifikasi salah satu kovenan maka ada akibat hukum bagi negara jika tidak melaksanakannya.

Oleh karena itu maka didalam membuat suatu peraturan yang sensitive gender perlu disusun indikator gender yang dijadikan dasar ukuran atau standar kesetaraan gender sehingga lebih mencerminkan asas manfaat dan rasa keadilan. Standar itu adalah: memasukkan bahwa hak asasi perempuan merupakan hak asasi dan mengintegrasikan dengan pendekatan akses, partisipasi, kontrol manfaat Kemudian didalam pembentukan suatu peraturan perundangn undangan, kebijakan yang berspektif gender perlu memasukkan beberapa teori yakni teori hak asasi manusia, kesetaraan gender dan kebutuhan gender.

Teori Kesetaraan gender adalah didalam kedudukan antara laki laki dan perempuan di masyarakat dapat merasakan haknya secara sama baik didalam mengakses, berperan diranah publik. Sehingga berbicara tentang kesetaraan gender bertujuan untuk mencapai keadilan gender. Keadilan gender akan terwujud jika perlakuan diskriminiasi tidak dirasakan oleh kedua jenis kelamin (https://idtesis.com/kesetaraan-gender2). Selanjutnya teori kebutuhan gender yang bersifat praktis diperlukan karena langsung dapat dirasakan manfaatnya oleh kedua jenis kelamin (Chinkin, 2001, hal 24). Untuk dapat dirasakan langsung khsusunya bagi perempuan maka 4 indikator gender seyogyanya dimasukkan secara terintegrasi mulai pada saat pembuatan suatu produk hukum, kemudian dijabarkan kedalam kebijakan dan program. Yang lebih utama adalah pada proses penegakan. Dapat dituangkan dalam bagan berikut ini: 


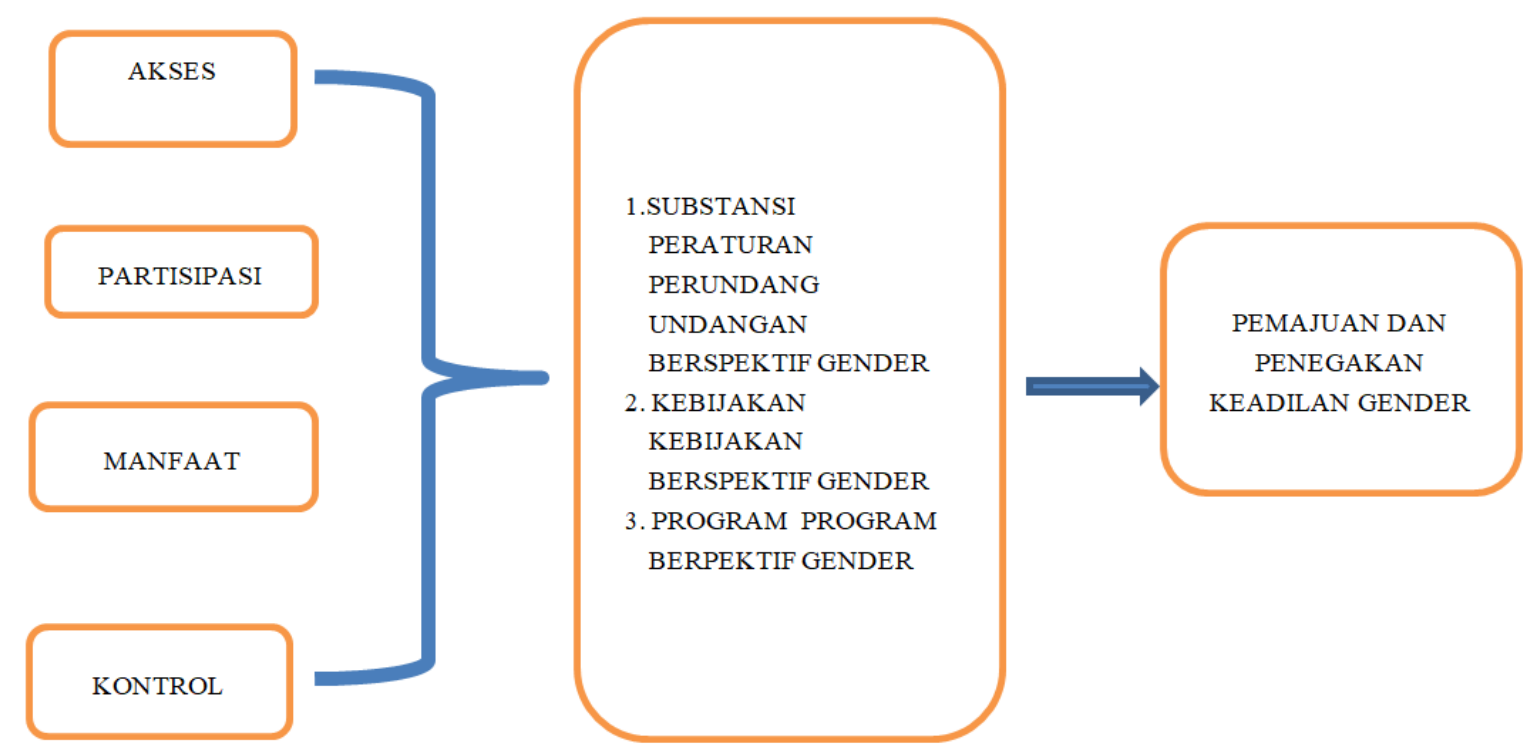

Akses, perlu mendapatkan perhatian untuk kedua jenis kelamin agar memperoleh akses yang setara sehingga didalam pembuatan substansi hukum mencerminkan kesetaraan dan rasa keadilan. Selanjutnya ada beberapa faktor yang perlu diupayakan oleh pemerintah untuk mencapai kesetaraan terkait informasi, sumber daya dan sosial budaya. Karena ketiga hal diatas sangat menentukan keberasilan implementasi suatu peraturan, kebijakan dan program yang berspektif gender di masyarakat.

Partisipasi, dengan memperhitungkan mulai dari peraturan, kebijakan dan program telah mengatur hak dan kewajiban masyarakat serta untuk ikut serta didalam kegiatan pembangunan. Pelibatan kedua jenis kelamin didalam memecahkan persoalan baik dilevel institusi maupun masyarakat.

Kontrol, dilakukan kajian terhadap peraturan, kebijakan dan program terkait kapsitas baik dilevel institusi mauapun masyarakat yang berkaitan dengan hubungan antara kedua jenis kelamin didalam melaksanakan hak dan kewajibannya. Kemampuan yang setara antara laki laki dan perempuan dijamin oleh peraturan dan diwujudkan dalam kebijakan dan program -program.
Manfaat, melakukan kajian terhadap substansi hukum untuk emnjamin bahwa kebiajkan dan program akan membawa manfaat yang setara untuk laki laki dan perempuan.

Untuk mengkaji dan mengalisis peraturan agar mengintegrasikan kesetaraan gender maka digunakan landasan filosofis, sosiologis dan yuridis. Dasar untuk menjawab kenapa indikator gender perlu dimasukkan kedalam peraturan perundang undangan karena beberapa hal yaitu landasan filosofis: bahwa setiap orang entah apa latar belakangnya, jenis kelamin, suku dll dapat memiliki dan merasakan hak yang setara sebagai manusia, manakala pemerintah masing masing negara mengaturnya didalam hukum positifnya. Deklarasi Universal Hak Asasi mengakui isi Deklarasi dan Program Aksi Wina Tahun 1993 yang menyatakan bahwa hak asasi perempuan merupakan bagian dari hak asasi manusia yang terintegrasi tidak dapat dipisahkan dan tidak dapat dicabut. Selanjutnya landasan sosiologis, upaya untuk mencapai kesetaraan gender memang telah dimasukkan kedalam beberapa peraturan perundang undangan dan kebijakan, namun dalam ralitasnya sampai saat ini kondisi perempuan dan 
anak masih belum sesuai dengan harapan. Data tentang tingginya angka kematian ibu melahirkan, kekerasan terhadap perempuan diranah publik dan privat, perdagangan anak serta meningkatnya anak sebagai pelaku tindak pidana. Adapun alasan utamanya tentang konsep bahwa hak asasi perempuan merupakan hak asasi manusia yang tercermin dialam berbagai peraturan perundangan undangan kebijakan. Kemudian landasan yuridis, Kedudukan setiap warga negara terkait dengan hak haknya diatur mulai dari ketentuan Undang Undang Dasar Negara Republik Indonesia Tahun 1945 (UUDNRI Thau 1945) dan peraturan perundang undangan. Didalam ketentuan Pasal 27 ayat (1) tentang kedudukan yang sama di depan hukum dan pemerintahan bagi setiap warga Negara dan tugas. Pasal 27 ayat (2) bahwa hak untuk memperoleh pekerjaan dan kehidupan yang layak. Diikuti lebih lanjut didalam pasal Pasal 28A sampai dengan Pasal 28J dan didalam ketentuan Pasal $28 \mathrm{H}$ ayat (2) dijelaskan bahwa setiap warga Negara memiliki hak untuk memperoleh kesempatan dan manfaat untuk memperoleh keadilan dan persamaan.

Dalam ketentuan Pasal 281 (2) dinyatakan bahwa setiap berhak bebas dari perlakuan diskriminatif dan perlindungan dari perlakukan diskriminatif itu. Untuk memberikan pemajuan dan perlindungan hak bagi setiap warga negara merupakan tugas Negara untuk itu. Sehingga langkah pertama untuk memberikan perlindungan maka negara seyogyanya mengatur dengan menuangkan didalam peraturan perundang undangan. Yang lebih khusus lagi untuk memberikan perlindungan bagi perempuan dari perlakukan diskriminatif dan mendapatkan hak haknya maka dimasukkan indikator gender. Setelah itu diikuti dengan programprogram dan aktivitas yang mewujudkan hak hak tersebut. Tugas negara dalam hal ini dilakukan oleh legislatif, eksekutif dan yudikatif untuk pemajuan dan perlindungan hak asasi warga Negara dan hak asasi perempuan.

Didalam Undang Undang Nomor Undang Nomor 39 Tahun 1999 Tentang Hak Asasi Manusia ada beberapa pasal yang dapat dijadikan rujukan secara yuridis yakni Pasal 2, 3 dan Pasal 45 menentukan bahwa hak perempuan didalam undang undang ini merupakan hak asasi dan dipertegas lagi didalam ketentuan Pasal 46-51 hak hak yang dimiliki oleh perempuan secara khusus. Kemudian didalam Pasal 71 ditentukan jika tanggung jawab ada pada pemerintah untuk melakukan pemajuan dan perlindungan. Aspek pemajuan dilakukan oleh pemerintah untuk memberikan pengetahuan melalui proses sosialisasi kepada semua elemen agar mereka mengetahui bahwa mereka memiliki hak. Proses memiliki hak ini lewat proses pengaturan didalam peraturan perundang undangan. Tujuannya adalah agar masyarakat dapat merasakan hak haknya. Untuk itu yang paling penting adalah mengimplementasikan peraturan tersebut kedalam kebijakan dan program program. Hal yang paling menentukan adalah melakukan kajian apakah masyarakat sudah merasakan hak haknya? Jika dikaji dari 4 indikator terkait kondisi perempuan ternyata dalam pelaksanaan masih harus diperjuangkan karena hambatannya dari faktor sosial budaya.

Konvensi internasional dibidang HAM sudah diratifikasi oleh Indonesia dan akan mengikat secara hukum (legally binding). Dimana ada beberapa kewajiban bagi Negara peserta untuk memasukkan prinsip konvensi internasional kedalam undang undang, untuk memberikan perlindungan dan pemajuan. Perlindungan diberikan untuk menjamin kepastian hukum manakala ada hak haknya dilanggar. Sedangkan aspek pemajuan merupakan tugas pemerintah untuk memberikan pengetahuan bahwa masyarakat tahu memiliki hak, kemudian dapat memiliki haknya melalaui pemgauran didalam hukum positifnya, akhirnya masrakat dapat merasakan hak haknya.

Ketika indikator kesetaraan gender dimasukkan kedalam setiap substansi hukum positif itu sudah seharusnya karena menurut ketentuan Penjelasan Pasal 6 ayat (1) huruf g dan h UndangUndang Nomor 12 Tahun 2011, sudah mewajibkan 


\section{Kajian parameter gender dalam substansi peraturan perundang-undangan di Indonesia}

Kadek Wiwik Indrayanti

memasukkan asas keadilan secara proporsional dan asas kesamaan. Asas kesamaan didalam setiap materi dengan prinsip tidak ada diskriminasi, pembedaan kepada setiap warga negara atau yang diberi kaedah tanpa membedakan jenis kelamin, agama, suku dll. Kemudian keempat indikator gender posisinya sama penting sehingga substansi menjadi sensitive gender.

Seperti diketahui bahwa pengintegrasioan gender sebagai strategi yang diinstruksiskan oleh United Nation untuk mencapai gender equality (2011: 8-12). Sehingga dengan menerapkan prinsip universal dalam pengintergrasioan gender ditegaskan bahwa budaya dan keberagamannnya, nilai nilai agama dan praktek tradisi tidak secara negatif berdampak pada perempuan. Prinsip itu adalah (a) Universality: semua orang perampuan dan laki laki memiliki hak asasi tanpa membedakan suku, agama, jenis kelamin dll. Tetapi warga dibanyak negara banyak masih berlanjut sebagai korban atas ketidak adilan dan perlakuan dalam semua aspek kehidupan (b) Indivisibility, interdependence and interrelatedness: bahwa hak itu tidak dapt dibagi bagi merupakan satu keasuan, saling tergantung satu dengan yng lainnya c) Participation and inclusion : Laki dan perempuan memiliki hak untuk mengakses informasi dan berpartisipasi dalam setiap proses pengambilan keputusan yang berdampak pada kehiduapannya. Dibawah hukum internasional hak asasi, negara diwajibkan untuk menjaga kebebasan dan partisipasi dibidang kehidupan politik dan ekonomi bagi kedua jenis kelamian dari semua usia, agar dapat memiliki dan statusnya. Pemberdayaan perempuan dibidang politik dan ekonomi sangat urgen d) Equality and non-discrimination: persamaan antara laki laki dan perempuan terkait dengan persamaan hak, tanggung jawab, dan kesempatan bagi laki laki dan perempuan. Pembuat peraturan dan kebijakan harus memperhatian persamaan dan harus diterapkan secara sama terhadap laki laki dan perempuan. Lebih lanjut prinsip non-diskriminasi sejalan dengan prinsip persamaan, seperti keketidak samaan, dalam frame work hak asasi dimengerti sebagai hasil dari diskriminasi.

\section{Simpulan}

Untuk mencapai kesetaraan gender maka yang harus dilakukan adalah mengingintegrasikan tujuan, prinsip, dan indikator kesetaraan gender dalam penyusunan undang - undang. Konsep kesetaraan gender sudah seyogyannya dipahami sebagai sebuah "Tujuan" untuk memperoleh hak haknya bagi kedua jenis kelamin sebagai warga negara. Dimana tujuan ke-5 adalah untuk mencapai kesetaraan gender dan pemberdayaan perempuan. Disamping itu 3 tiga hal prinsip yang harus mendapatkan perhatian yaitu kesetaraan mendasar, non diskriminasi dan kewajiban Negara yang menjadi pintu pembuka untuk memperbaiki kondisi ketidak setaraan gender dimasyarakat. Kemudian parameter kesetaraan gender yang terdiri atas akses, partisipasi, kontrol dan manfaat seyogyanya dimasukkan didalam pembuatan peraturan perundangan, kebijakan dan program-program. Hal itu didasarkan didalam substansi peraturan perundang undangan masih bias gender dalam arti belum memberikan hak hak perempuan dengan setara dan adil.

\section{Daftar pustaka}

Astutty, M. Dewi and Indrayanti, K. Wiwik. 2020. Development in handling of violence against women by implementing the approach of gender managements system: Study in the environment of agencies in Waingapu District, East Sumba Indonesia. Academic Research International, September Vol.11(3). h t t p s : / / w w w . s a v a p.org.p k www.journals.savap.org.pk.

Chinkin, C. 2001. Gender Mainstreaming in Legal and Constitutional Affairs, 2001. United Kingdom.

Gender Equality Policy, 2011. United Nations Human Rights.

https:// daerah.sindonews.com/read/297502/704/ januari-september-2020. 


\section{Jurnal Cakrawala Hukum, Volume 12 No. 2 Agustus 2021}

ISSN PRINT 2356-4962 ISSN ONLINE 2598-6538

https://idtesis.com/kesetaraan-gender-2.

https://nasional.kompas.com/read/2016/03/06/ 17335421/Diskriminasi.Gender.Tujuh. UU.Terkait.Perempuan.

https:// wolipop.detik.com/worklife/d-4866087/2aturan-omnibus-law-yang-merugikan-pekerjawanita-kamu-wajib-tahu.

https://www.merdeka.com/peristiwa/25-persenmasyarakat-indonesia-melakukan- nikahsiri.html.

https://www.un.org/en/africa/osaa/pdf/au/gender policy_2009.p.

LBH APIK dalam http://mappifhui.org/wp-content/ uploads/2018/01/Pedoman-Mengadili-PerkaraPerempuan-Berhadapan-dangan-HukumMaPPI-FHUI-2018.pdf.

Mochtar, A. Dewi and Indrayanti, K. Wiwik. 2019. Potrait of gender perspective policies and programs in the Sumba district office : Learn from the impact of barsha pump usage on access water for farmer. Academic Research International. Vol 10 (3) September 2019. https:// www.journals.savap.org.pk.

Mulyono, G. P., \& Yosafak, H. 2020. Analisis Fenomena Perilaku Penyimpangan Seksual (LGBT) di Indonesia dalam Pandangan Hukum Asasi Manusia. Yurispruden: Jurnal Fakultas Hukum Universitas Islam Malang, 3(1), 12-23.

Parameter Gender Didalam Pembentukan Peraturan Perundangan. 2011. Kementerian Hukum dan Hak Asasi Manusia Republik Indonesia, Kementerian Pemberdayaan Perempuan dan Perlindungan Anak.

Pembangunan Manusia Indonesia berbasis gender. 2019

Sonia Akter a, Pieter Rutsaert b, Joyce Luis b, Nyo Me Htwe c, Su Su San c, Budi Raharjo d, Arlyna Pustika. Women's empowerment and gender equity in agriculture: A different perspective from Southeast Asia. 2017. Food Policy. Vol 69.

The Convention for the Elimination of All Discrimination Against Women (CEDAW). 